\title{
Does Protest "Distract" Athletes from Performing? Evidence from the National Anthem Demonstrations in the National Football League
}

Forthcoming in the Journal of Sport and Social Issues

\author{
Daniel N. Hawkins, ${ }^{1}$ Andrew M. Lindner, ${ }^{2}$ Douglas Hartmann, ${ }^{3}$ and Brianna Cochran ${ }^{2}$ \\ ${ }^{1}$ Department of Sociology \& Anthropology, University of Nebraska Omaha \\ ${ }^{2}$ Department of Sociology, Skidmore College \\ ${ }^{3}$ Department of Sociology, University of Minnesota
}

\begin{abstract}
Author Note
We have no know conflict of interest to disclose.

Correspondence concerning this article should be addressed to Dan Hawkins, Department of Sociology \& Anthropology, University of Nebraska Omaha, 6001 Dodge St., Omaha, NE, 68182. Email:

dhawkins@unomaha.edu.
\end{abstract}




\title{
Does Protest "Distract" Athletes from Performing? Evidence from the National Anthem Demonstrations in the National Football League
}

\begin{abstract}
While there is a long tradition of activism within sport, a popular criticism of athlete protest is that it is a "distraction" that hinders on-field performance. The widespread demonstrations against racial injustice in 2017 among players in the National Football League (NFL) provided an opportunity to test this "distraction hypothesis." Using data drawn from multiple sources, we first explored which factors predicted player protest, finding that Black players and those playing for underdogs were more likely to protest. Then, using a series of analyses at the player-game level $(n=19,051)$ and the team-game level $(n=512)$, we tested the assertion that protest is detrimental to individual or team performance, finding no evidence for a distraction effect. The results of this study allow us to better understand social factors that may affect athletic performance or constrain athlete activism.
\end{abstract}

Keywords: athlete activism, American football, distraction, performance, protest, race 


\section{Does Protest "Distract" Athletes from Performing? Evidence from the National Anthem}

\section{Demonstrations in the National Football League}

While there is a long tradition of activism in sport, there is also an equally long tradition of opposition and backlash against any form of protest in the athletic realm (Agyemang et al., 2020; Bryant, 2018; Hartmann, 2019; Nauright \& Wiggins, 2017; see also Ratchford, 2012; Ruffin, 2014). Some critics stand against athletic activism simply because they oppose the interests, ideals, or positions of athlete activists. But most of the popular opposition has more elaborate, even principled justifications: that athletic protest is a violation of labor agreements; the cultural belief that athletes are expected to remain silent; that protest sullies the entertainment value of sport, its status as a distraction and release from the quotidian issues, challenges, and events of the day; and, of course, the deeper prohibition for keeping politics out of sport. This paper examines another of the most common popular arguments against athletic activism, indeed one of the most frequent and seemingly widely-accepted criticisms from within the sporting establishment itself: the claim that sports-based protest activities by athletes undermine the onfield performance of athletes themselves. More specifically, many coaches, commentators, fans, and even players believe that political or social protest before games is a distraction that elite athletes cannot afford to participate in without adversely affecting their ability to compete and to win.

This belief — which we will call the "distraction hypothesis" and discuss at length shortly—is frequently invoked and widely held, yet, as far as we know, essentially untested. Our goal in this paper is to provide an initial and hopefully compelling analysis of this claim. The analysis presented here is focused on the widespread protests of racial injustice in the United State among players in the National Football League (NFL) during the 2017 season that emerged in the wake of Colin Kaepernick's “take a knee" demonstrations the season before. Using data drawn together from multiple, previously untapped sources, we first provide context for our analyses of performance by examining whether participation in this wave of protests varied by players' race, age, position, salary, and contract length. Next, using a series of statistical models at the player-game level $(n=19,051)$ and the team-game level $(n=512)$, we test the assertions that protest participation hinders the in-game performance of individual players or of their 
teams. The findings that result provide persuasive empirical evidence that challenges popular beliefs that athlete activism inhibits or diminishes on-field athletic performance, and allow us to better understand factors that may constrain professional athletes' participation in protest. The paper concludes with a discussion of the implications of these results for our theories of sport, protest, and politics, as well as for sport performance studies about the impacts of non-sport, social, and cultural factors for on-the-field athletic performance.

\section{Background}

The most recent wave of protest in American professional sport has inspired a provocative and increasingly developed new body of research on the roots and motivations of athletic activism (Cooper et al., 2017; Cunningham \& Regan, 2011; Cunningham et al., 2019; Gill, 2016; Govedsouzin, 2017; Hartmann, forthcoming; Lee \& Cunningham, 2019; Nepsted \& Kenney, 2018). This work builds off of a longer standing body of theory and research involving athletic protest and activism (Agyemang et al., 2010; Kaufman, 2008; Kaufman \& Wolff, 2010), much of which was itself derived from and based upon incidents, events, and research with a more international or Olympic context (Boykoff, 2017; Kilcline, 2017; O’Bonsawin, 2015). Here also it may be worth noting the inordinate attention that race has received in athletic activism both domestic and international. This is both because Black athletes have been such leaders and because of the enduring iconic touchstone of athletic activism: Tommie Smith and John Carlos's clenched fist salute on the victory stand at the Mexico City Olympic Games in $1968 .{ }^{1}$

As with more general research and theory on social movements, this body of work has focused on struggles of recruitment, organization building, and tactics. This includes work on social networks in engaging activism (Houghteling \& Dantzlen, 2019); economic pressures and constraints (Dodson, 2016; Niven, 2019); movement tactics (Nepstad \& Kenney, 2018); and increasingly, the role and leadership of female athletes (Cooky and Antunovic, 2020; Lavelle, 2019). Issues of media and communication have

\footnotetext{
${ }^{1}$ There is a large literature on the events of 1968 (Bass, 2004; Edwards, 2017 [1969]; Hartmann, 2003). See also: Brooks \& Althouse, 2009; Harris, 1995; Hartmann, 2009; Marinelli, 2008; Polite \& Hawkins, 2012; Ruffin, 2014; Wiggins, 1988.
} 
also been well studied: among athletes themselves (Schmittel \& Sanderson, 2015); between athletes and the larger public (Coombs \& Cassilo, 2017; Schmidt et al., 2018); and on the role of team-operated media professionals in framing news and information (Mirer \& Grubic, 2019). The field has even produced a new typology of athletic activism (Cooper et al., 2019). This work has contributed not only to our understanding of sport in society, it has expanded our understanding of social movement organizing and the role of media/communications in a new era of both professionalization and polarization. However, with some notable exceptions (Cunningham \& Gill, 2016; Dickerson \& Hodler, 2020; Johnson, et al, 2020; see also: Kaufman, 2008), scholars so far have paid less attention to the strong opposition and backlash activism in and around sport typically generates in the athletic establishment, among sportswriters and commentators, and among the American public in general.

\section{Criticisms of Protest in the Sports Realm}

There are many variations of criticism against athletic activism, racial and otherwise, and many of these apparent in the public discussions and debates that unfolded in the fall of 2017 with President Trump's attacks on activist-oriented athletes. Some critics have construed athlete protest as a legal or first amendment/free speech issue. Others think of it more as a labor issue, focusing on contracts and agreements between leagues and conferences and their players or unions, with unpaid collegiate athletes ironically receiving some of the harshest implied sanctions against speaking out (Agyemang et al., 2010). One of the most common refrains among sports fans and American sports reporters who oppose athletic activism is a sense of frustration, annoyance, or exhaustion derived from the belief that the sports world is simply not the right place for such demonstrations, discussions, and debates. Even if critics sympathize with the players and their social and political views, they do not believe sports is the proper venue, especially not during the crucial moment of the national anthem or other traditional ceremonies or rituals (Smith \& Tryce, 2019).

At least two different variations on this theme have played out (see Hartmann, 2019). One comes from fans (and others) who see sport as purely a form of entertainment. These folks watch sports precisely for the purpose of getting away from the regular news, from the muddy complexities and social conflicts 
of everyday life. This low-brow, don't-want-to-be-bothered form has yielded some extreme and often racially-charged reactions ("shut up and play"), but generally it is seen in the more innocuous request for sports to just be a site of leisure, a distraction, or even an escape. Other protest critics take a higher road. In this second, more idealistic view, the athletic realm stands—or at least is supposed to stand — on higher moral ground than other popular pursuits. According to this way of thinking, sports, when practiced properly, are believed to be an inherently positive social force-breaking down barriers, transcending the social fray, and contributing to unity, solidarity, and a larger social good. And the inverse implication of this is that activism and protest should not be necessary. At the root of both of these orientations are strong beliefs and deep cultural norms about needing to protect sport from all political issues and influences (see also Green \& Hartmann, 2012).

More recently, a related but distinct third theme has developed that seeks to delegitimize and derail athlete activism (see, for example, Bieler, 2017; Clarke \& Maske, 2018; Galily 2020; Jensen, 2017; McManamon, 2017; Steele, 2018). As athletes, teams, and organizations increasingly look for any edgeboth physical and psychological— to succeed in the world of elite sports, any pregame activity that would interfere with subsequent athletic performance is discouraged or disallowed by non-athlete stakeholders, including team owners, coaches, fans, and the media. They argue that protest does not "belong" in the sports realm because it is a distraction from the most important aspect of sport - the competition itself. In other words, athletes who protest before a game are inhibiting their own ability to perform at the necessary highest levels. The 2017 NFL national anthem protests serve as a valuable case study in examining the veracity and utility of this third line of reasoning.

\section{The 2017 National Anthem Protests in the NFL}

Before examining the distraction hypothesis in more detail as it relates to the recent NFL anthem protests, it is worth outlining a brief history of this most recent chapter of athlete activism in pro football. And we should begin by acknowledging that a good deal of the recent literature on athletic protest focuses on this specific episode (see Chaplin \& Montez de Oca, 2019; Houtghteling \& Dantzler, 2019; Intravia et 
al., 2017; Nepstad \& Kenney, 2018; Niven, 2019; Weffer et al., 2018), which we draw on in part in shaping the overview below.

Before the start of the 2009 season, the NFL mandated that players stand on the field during the national anthem; prior to this, most teams stayed in the locker room until the anthem had ended. In the first three games of the 2016 preseason, San Francisco 49ers quarterback Colin Kaepernick chose to sit on the bench rather than stand on the sidelines during the playing of the national anthem. Kaepernick revealed in an interview with NFL reporter Steve Wyche (2016) that he was protesting the historical and contemporary mistreatment of racial minorities in the United States, particularly in reference to recent police killings of unarmed African American men. He would not "stand up to show pride in a flag for a country that oppresses black people and people of color."

Following the reporting of this original form of the anthem protest, former Green Beret and NFL player Nate Boyer wrote an open letter to Kaepernick in late August of 2016 (Brinson, 2016). Although Kaepernick had explicitly stated to reporters that his protest was not intended to dishonor the flag or criticize the military, Boyer explained in his letter how some American troops nevertheless viewed sitting on the bench during the anthem as disrespectful and even hurtful. After an in-person meeting that included 49ers safety Eric Reid, Kaepernick and Boyer agreed that taking a knee during the anthem would be a more reverential yet still powerful method of protesting (Wagoner, 2016). Boyer, standing with hand over heart, joined a kneeling Kaepernick on the 49ers' sideline for the final preseason game. Reid knelt with Kaepernick for the subsequent regular season games, and other NFL players from across the league also engaged in forms of protest during the national anthem as the season progressed; sometimes they knelt like Kaepernick and Reid, but more often they made other symbolic gestures such as raising a fist or linking arms. Throughout, the protests were controversial and provoked no small degree of opposition and backlash (Dickerson \& Hodler, 2020)

At the start of the 2017 season, Colin Kaepernick was no longer employed in the NFL, but the protests he had inspired continued. The suspected "blackballing" of Kaepernick from the league (addressed again at the end of the paper) likely further ignited the players' desire to support him and his 
cause, while the NFL's failure to prohibit or punish protesting players spurred on the fan backlash and calls for boycotting the league. And then, before the third week of the regular season, President Donald Trump weighed in on the protests both on Twitter and at a political rally. He echoed and amplified much of the anti-activist sentiment that had been growing in the public (Chaplin \& Montez de Oca, 2019), calling the protests disrespectful to the "Flag \& [the] Country," and even suggesting that when a player kneels, NFL owners should "get that son of a bitch off the field" and fire them (Tatum, 2017; Montez de Oca \& Suh, 2020). This led to large scale protests by NFL players the following two Sundays, including the strange image of some NFL owners locking arms or even kneeling with the players, though not during the anthem. These unusual week three and four protests were more of a repudiation of Trump's attack on the NFL and a gesture of solidarity across the entire league than expressed support for Kaepernick's cause; by the fifth week, the protests had returned to "normal," with activist players kneeling or otherwise protesting during the anthem (Nepstad \& Kenney, 2018; Weffer et al., 2018).

\section{The Distraction Hypothesis}

A directly performance-oriented version of the "shut up and play" reaction to athlete protest (Galily, 2020), like that during the 2017 NFL season, is the argument that any and all activities not expressly related to the game at hand distract or inhibit players and teams from competing at the highest level. This tactic is different from other protest "neutralization strategies" (Nepstad \& Kenney, 2018) in that it purportedly does not consider factors or costs outside of the game itself. In fact, some NFL team owners and coaches have nominally supported their players' right to protest — or at least have not taken issue with their political or social views. Instead, the argument against players' expressing their views through protest relies on a narrative that opposes any disruption in team focus and function. Presumably, there is nothing an NFL owner or coach wants to keep out of his or her locker room more than a "distraction" from the single-minded goal of winning.

On its face, this narrative appears politically neutral, but the de facto result is still the silencing of social protest in the sports arena; specifically, the message becomes clear that politically active playersor at least those without overwhelming talent—will not be employed by the NFL (or other sports 
leagues). Yet, the distraction hypothesis may not be solely applied to activist players: Michael Sam, the 2013 Defensive Player of the Year in the nation's preeminent college football conference (the SEC), was not drafted until the final round of the 2014 NFL draft and never played in a regular season game. He was the first and remains the only openly gay player to ever declare for the NFL draft. Former NFL head coach Tony Dungy publicly stated that he would not have taken Sam in the draft to avoid having to "deal with all of it," although he later clarified that he was referring to the media coverage that would surround Sam's attempt to make the team and not Sam's sexual orientation itself (Farrar, 2014).

The distraction hypothesis might be attractive to NFL owners, who are fully aware of the potential costs to their business and reputation—-sometimes referred to as a failure to protect "The Shield"-if fans view players' political activities in an unfavorable light. They can appear to be committed to winning by cutting "distracting" players, while simultaneously comporting with their generally politically conservative natures. NFL coaches, with their notorious desire to have full control of players' activities and schedules, at least during the season (Van Valkenburg, 2013), may actually be "true believers" in the distraction hypothesis. An extra win or two during the regular season can be the difference between an NFL head coach being fired or signing a contract extension, creating enormous pressure to keep the team's sole focus on winning football. For the media and fans alike, the distraction hypothesis may feel like a sensible post hoc explanation for team performance, particularly if the team they cover or follow is not living up to expectations that game or that season.

\section{Potential Effects of Protest on Individual Performance}

In a team sport, such as professional football, the distraction caused by protest may diminish performance at both the individual and group level. In terms of basic physical performance, there is a large body of research that demonstrates that distractions imposed on study subjects by researchers (noises, obstacles, disturbances in the field of vision, etc.) impair multiple aspects of motor behavior (e.g., Grabiner \& Troy, 2005; Sheik-Nanier et al., 2015; Weerdesteyn et al., 2003). Distractions negatively affect concentration and pull cognitive resources away from the completion of motor behavioral tasks. It may be that residual thoughts and feelings about participating in protest increases the cognitive load and 
stress levels of protesting players, thereby inhibiting their athletic performance at a basic physical level. Yet, it is important to note that the bulk of these motor behavior studies use experimental manipulation of distraction in artificial environments and involve distractions imposed during rather than before the performance of physical task. Whether the effects of distraction on motor behavior extend to competitive athletic contests is untested, particularly when the distracting behavior itself has ended by the time the game starts.

In natural competitive environments, protest may be a distraction that interferes with preparation for the game at hand. Elite athletes rely on regimented pregame routines to prepare physiologically and psychologically for competition, and there is some evidence that athletes are more likely to employ these routines (or "rituals") during more important games when the outcome is more in doubt (Schippers \& Lange, 2006). However, the effect of these pregame routines on subsequent performance appears to be understudied in the literature relative to the large body of research on pre-performance routines and their outcomes (Cohn, 1990; Hazell et al., 2014). A pre-performance routine refers to a "sequence of task relevant thoughts and actions which an athlete engages in systematically prior to his or her performance of a specific sports skill” (Moran, 2016). For example, each time a football kicker lines up to attempt a field goal, they may take a deep breath, envision the ball sailing through the uprights, and then focus on the holder's hands before the ball is snapped. These systematic routines have been shown to increase success by reducing anxiety and tension before the specific athletic action (Cohn, 1990; Hazell et al., 2014).

Of course, many plays in football are not as discrete or contained as a field goal attempt, but are instead split-second organic reactions to the actions of other players on the field. Still, pregame routines may theoretically function similarly to pre-performance routines by reducing anxiety at a broader game level than at the level of a discrete skillful act (Glazier, 2017). The act of protest before a game may start a negative feedback loop between interruption of pregame routines and anxiety, which is the most prominent psychological constraint on sports performance in general (Glazier, 2017; Zaporzan, 2019). Protesting players may be understandably anxious about the way coaches, teammates, fans (friendly or 
not), and the media will react to their planned protests, and this may be on their minds during their pregame routines. The routines are therefore interrupted or less effective, thereby creating even more pregame anxiety. The inability to reduce anxiety and increase focus through pregame routines thus potentially diminishes subsequent in-game performance.

\section{Potential Effects of Protest on Team Performance}

While the relationship between distraction and team performance is understudied in the sports realm, there is work on contemporaneous distraction and team functioning that may serve as a useful comparison, particularly from medical studies. In observational studies of surgical teams, natural distractions in the operating room (loud background noises, movement into and out of the room, cell phone notifications, etc.) decrease attention and working memory and increase cognitive stress, causing errors and inhibiting cooperation (e.g., D'Esmond, 2016; Gui et al., 2021; Wheelock, et al., 2015). These mistakes can cascade, leading to further errors and causing resentment among team members, potentially affecting future team performance as well. But as with the research on distraction and motor behavior, it is critical to note that the distractions observed in these operating room studies occur during the performance of the surgery itself rather than in the preparatory phase.

For a professional football team, it seems more likely that protest has negative effects on subsequent team performance through various mechanisms that hinder team cohesion. Team cohesion is a "dynamic process that is reflected in the tendency of a group to stick together and remain united in the pursuit of its instrumental objectives and/or for the satisfaction of member affective needs" (Carron et al., 1998). In the NFL, winning each game by as many points as possible is the clear instrumental objective, and the immediate thrill of winning, along with the associated financial rewards and prestige that accrue, would likely satisfy most if not all individual players' affective needs as well. Recent meta-analytic studies of the effect of team cohesion on both subjective and objective measures of team performance have consistently found a moderate positive relationship (Carron et al., 2002; Dobersek et al. 2014; Filho et al., 2015). Although task cohesion — the ability to work together to achieve a common goal—is most 
strongly related to athletic success, social cohesion also has a significant effect on team performance (Filho et al., 2015).

Pregame protest may diminish team cohesion — and subsequent game success — in a few different and potentially additive or even multiplicative ways (Zaporzan, 2019). First and most prominently, protesting players may be viewed by teammates and coaches as putting themselves above the team. They may simply be seen as "grandstanding" by refusing to conform with accepted team protocol, or potentially even more harmfully, their dedication to the team and focus on winning may be questioned due to bringing "outside" activities into the "workplace." Second, active protest, intentionally or not, may lay bare existing but unacknowledged cultural, social, racial, and religious divides within a locker room. In this way, protest is viewed as a direct violation of the "sport as a sacred space" maxim still adhered to by many players and coaches (Hartmann, 2019). Finally, the threat of protest may actively distract nonprotesting players from their own pregame routines, thus fomenting resentment toward activist players.

\section{Other Relevant Factors}

Since our interest is in isolating the relationship between protest participation and subsequent game performance, we control for several factors at both the individual and team level that may confound this relationship. To start, we control for each players' race, age, and position. Given that the motivation for the protest is to draw attention to police violence toward African American men, that the majority of NFL players are Black, and that race has been central to athletic activism (e.g., Brooks \& Althouse, 2009; Bryant, 2018; Polite \& Hawkins, 2012), player race is a key control (although we do not hypothesize a particular relationship between race and performance). In contrast to race, player age has a clear curvilinear relationship to performance, as players tend to improve on average from the beginning of their careers through their "prime" ages and decline thereafter. In terms of willingness to protest, there may be generational divides concerning the urgency of issue and the legitimacy of using public protest to address it. Some positions in football, such as the offensive skill positions of quarterback, running back, and wide receiver, are more prominent and may affect protest decisions, and it is also possible that our measure of player grades is related to player position. We importantly control for two variables-length of current 
contract and current salary — that both represent players' economic vulnerability as it relates to their willingness to protest (Coombs et al, 2019; Niven, 2019), as well as their expected performance level. In terms of broader contextual factors, the location of the game and the political leanings of the fans in the stands may influence players' protests decisions (Coombs et al, 2019; Niven, 2019). We also control for whether the games took place in the third and fourth weeks of the 2017 NFL season, in which reaction to President Trump's comments may have temporarily affected the quantity and nature of the protests.

\section{Research Questions}

In examining the distraction hypothesis using protest and performance data from the $2017 \mathrm{NFL}$ season, we address the following questions:

1) What are the characteristics of players who knelt or engaged in other forms of protest before games?

2) Are kneeling or other forms of pregame protest related to individual player game performance?

3) Are kneeling or other forms of pregame protest related to team game performance?

\section{Method}

The data for this study were drawn from multiple sources: 1) protest measures from the ESPN NFL Nation blog; 2) player performance, playing time, and position measures from Pro Football Focus; 3) player age and contract information from Sportrac; 4) player profile photos used to code for race from NFL.com; 5) team performance measures from NFL.com (final score) and FootballLocks.com (betting spread); and 6) crowd partisanship measures from FiveThirtyEight. This information was assembled into two datasets: one at the player-game level $(n=19,051)$ and one at the team-game level $(n=512)$. Descriptive statistics for all measures are listed in Table 1. We describe each of the datasets and the associated measures in turn.

\section{Protest}

We coded data on player protests using a list reported and maintained by the ESPN NFL Nation blog during the 2017 NFL regular season (ESPN.com staff, 2017; the week 17 blog post contains links to all previous weeks of the season). Several other media outlets recorded player protests, but none were as 
consistent or comprehensive as ESPN; the ESPN reports have been used and validated by other scholarly studies on the anthem protests (e.g., Houghteling \& Dantzlen, 2019; Nepstad \& Kenney, 2018; Niven, 2019). For each player-game, we recorded whether the player was mentioned by name as kneeling during the anthem $(1=y e s, 0=n o)$ or engaging in any other form of protest during the anthem $(1=y e s, 0=n o)$. Nonkneeling forms of protest included actions such as linking or locking arms with other players, raising a fist, placing a hand on a kneeling player's shoulder, and sitting during the national anthem. In some cases, the blog referenced "a small group of players" or "the entire offensive line" engaging in some protest. At the team-game level, we used this information to construct measures of the estimated number of players kneeling per game and the estimated number of players engaged in other protest per game. In $87 \%$ of cases for kneeling and $88 \%$ of cases for other protest, there was no difference between the number of players reported by name as protested and the estimated total.

\section{Player Variables}

Due to the range of statistics used to assess players in different positions, we selected Pro Football Focus's (PFF; n.d.) overall grade (0-100) as our primary measure of player performance. These standardized scores — based on evaluations of every play made by every player in every game — allow for direct comparisons of players in various offensive and defensive positions. These grades are among the most widely-cited indication of how well or poorly a player performed in a given game by pro football writers and have been used in recent scholarly studies of NFL player performance (e.g., LaPlaca \& McCullick, 2020). The PFF database also provided data on total snaps played per game and position played, coded as defensive position, offensive lineman, and offensive skill position (reference category). Several players played in multiple positions in a game, in which case PFF assigned them multiple grades. In such cases, we computed a weighted average of the overall grade based on how many snaps were played at each position. Because PFF does not produce grades for players that play exclusively on special teams, they are excluded from our player-game level analysis. All players, however, are included in the estimated team-game level measures of protest. Data on the individual player's age (in years), salary, and 
years remaining on contract were gathered from Spotrac (n.d.), a leading source of sports contract information online. Salary was recoded into millions of dollars.

Although the NFL Players Association does gather information on players' racial selfidentification, those data are not available to the general public. Following previous studies of race and sport (e.g., Gius \& Johnson, 2000; Kahn, 1992; Volz, 2017), two of the researchers coded 1,834 players for their race. The players were coded as White, Black, other race, or cannot be determined. Twenty percent of the sample $(n=367)$ were double-coded by the researchers as a reliability check. Using Krippendorf's alpha, the preferred measure of reliability in content analyses, the double-coded data achieved an alpha of .954 . This level of reliability was well above the .8 level of agreement that Krippendorf (2013) regards as standard. The small number of "cannot be determined" cases were reconciled by the researchers. The race measure was dummied at the player-game level (1=Black, $0=$ other race) and was computed as a percent Black at the team-game level.

\section{Game Variables}

Results for all games played in the 2017 NFL regular season, as well as whether a game was played at home or away, were collected from NFL.com (n.d.). Game results were recoded into the number of points by which the team won or lost (ranging from -43 to 43 ). We also gathered data on the betting spread prior to the game from FootballLocks.com (n.d.), a website that tracks gambling odds for football. A negative spread value (e.g., $-x$ ) indicated a team was favored to win by $x$ points, while a positive value meant a team was expected to lose by that specified number of points. We computed a measure of overor under-performance by adding the betting spread to the actual game spread. For example, a team with a betting spread of -6 (favored to win by 6 points) that actually won the game by only 4 points had a value of -2 , indicating under-performance by 2 points.

Finally, as a measure of the political leanings of the crowd in attendance at the games, we drew on data collected by FiveThirtyEight, a data journalism web site. From September 1-7, 2017, FiveThirtyEight commissioned SurveyMonkey to survey 2,290 American NFL fans, collecting enough cases for each team to ensure a representative sample (Paine et al., 2017). Using those results, they 
estimated the partisan lean of each team's fanbase. We used these estimates to approximate the mean partisan lean of the fanbase at the home stadium on each game day $(1=$ Democrat, $2=$ Independent, $3=$ Republican $).{ }^{2}$ While other researchers have used metro area measures of political partisanship (e.g., Watanabe \& Cunningham, 2020), the FiveThirtyEight data have the advantage of capturing the partisan lean of the crowds that players likely faced inside stadiums. To assess the backlash to President Trump's comments regarding NFL players, we created a dummy variable for weeks 3 and 4 ( $1=$ weeks 3 or $4,0=$ all other weeks).

\section{Analytic Approach}

For the first research question (who protested?), we began with a series of figures exploring the patterns of protest by week and position. Next, at the player-game level, we estimated a series of multinomial logistic regression analysis, clustered on player to adjust standard errors for the nonindependence of games by the same player. ${ }^{3}$ To conduct this analysis, the protest measures were recoded into a categorical measure $(0=$ no protest, $1=$ other protest, $2=$ knelt during anthem $)$. Presented in Table 2 are relative risk ratios with no protest as the base outcome.

To test whether protest was a distraction at the player-game level, we ran a series of linear regression models with random effects on player using PFF overall player grade as the outcome variable (Table 3). The test the same hypothesis at the team-game level, we used our measure of over-performance relative to the betting spread as the outcome variable. We present a series of figures depicting the bivariate relationship between estimated protest levels and over-performance. We also present the results of a linear regression analysis, clustered on game to adjust for the non-independence of cases in the same game (Table 4).

\footnotetext{
${ }^{2}$ The NFL held four games abroad (three in London and one in Mexico City). For those cases, we treat the partisan lean of the home stadium as missing data. For this reason, we dropped these four games (and the associated player performances) from models, which include the home stadium partisan lean measure.

${ }^{3}$ As a robustness check, we estimated multilevel logistic models with random effects on player, treating both protest variables as binary measures. Because kneeling during the anthem is an exceedingly rare event, we also estimated penalized maximum likelihood models for that measure. While some levels of statistical significance changed slightly between models, the magnitude of the effects of the independent variables was remarkably consistent. While all other models are available upon request, we present only the multinomial logistic model here for brevity's sake.
} 


\section{Results}

Given all the public attention to athlete protests during the 2017 NFL season, it is ironic that for most weeks of the season acts of protest were quite rare. As seen in Figure 1, with the notable exception of weeks 3 and 4, less than 10\% of NFL players knelt during the national anthem or engaged in other forms of protest. In the immediate aftermath of President Trump's comments, nearly $45 \%$ of players participated in forms of protest other than kneeling. Even then, kneeling during the national anthem remained quite rare, a form of protest adopted by only $5 \%$ of players. Per team, across the entire season, the average number of players kneeling per during the national anthem was 0.72 and the average number of players engaged in other protest was 5.39 (see Table 1). However, these averages concealed great variation across weeks, teams, and players.

\section{Who Protested?}

To answer our first question — what are the characteristics of players who knelt or otherwise protested before games - we turned to a multinomial logistics regression analysis. Recall that the unit for the analysis was an individual player in an individual game (i.e., player-game). Table 2 reports the relative risk ratios of a player in a game participating in other protest and kneeling during the national anthem (respectively) as compared to the base outcome of not protesting. Examining Model 1 for "Other Protest," none of the player characteristics, including race, age, contract, salary, or position, had a statistically significant effect on the relative risk of engaging in other protest as opposed to no protest. Model 2, which incorporates characteristics of the game itself, revealed several significant results. Predictably, players in games held in week 3 and 4 had 31.7 times the likelihood of engaging in other protest compared to games in other weeks $(p<.001)$. For each point more Republican-leaning the stadium crowd (on a 3-point scale), there was a lower chance of participating in other protest $(p<.001)$. Each additional point of disadvantage in the betting spread further increased the likelihood of other protest by players $(p<.001)$.

Model 3 incorporates measures of how many other members of team knelt during the anthem or engaged in other protest. Each additional teammate who participated in other protest increased the 
likelihood of a player engaging in other protest by $11.4 \%(p<.001)$. By contrast, teammates kneeling during the anthem had no significant effect on other protest. The previously significant game measures remained statistically significant, though the magnitude of the weeks 3 and 4 dummy variable was greatly reduced to 3.162. Playing at home reduced the chance of other protest by $18.6 \%(p<.01)$. Additionally, once controlling for other factors, Black players had a $62.2 \%$ increase in the likelihood of participating in other protest compared to non-Black players $(p<.05)$. Regarding forms of protest other than kneeling, it appeared that playing at home, facing a Republican-leaning crowd, and being favored in the betting odds reduced the chance of engaging in other protest. Having teammates protesting and the wave of weeks 3 and 4 increased the other protest. Of player characteristics, only being Black increased the chance of other protest.

Turning to the multinomial logistic results for kneeling during the anthem (Model 3 in Table 2), holding all else equal, we found that Black players had 27.8 times the chance of kneeling during the anthem compared to non-Black players $(p<.001)$. For each additional million dollars in salary a player earned, there was an $11.7 \%$ increase in the likelihood of kneeling during the anthem. Controlling for these characteristics, factors like age, years on contract, and position had no effect. As with other protest, being favored by sportsbooks $(p<.001)$ and playing in front of a more Republican-leaning crowd $(p<.05)$ reduced the chances of kneeling during the anthem, while playing in games in weeks 3 and 4 increased the likelihood of kneeling by $339 \%(p<.001)$. If other protest was somewhat less likely when playing at home, players were 2.461 times as likely to kneel during the anthem at home $(p<.001)$. Finally, players were much more likely to kneel during the anthem if more of their teammates were kneeling $(7.2 \%$ increase in the likelihood for each additional teammate, $p<.001)$ and/or engaging in other protest (4.4\% increase for each additional teammate, $p<.001)$.

\section{The Distraction Hypothesis}

We first considered the possibility that pregame protest affected individual player performance by examining the player's overall grade in a given game (see Table 3). Even casual football fans will be unsurprised to learn that players with higher salaries, with longer contracts, and who play more snaps 
tended to receive higher overall player grades (all $p<.001)$. Players on teams expected to do worse by sportsbooks tended to have worse grades $(p<.001)$. Overall grades were consistently lower for offensive linemen and consistently higher for defensive players compared to other positions. Factors including age, race, Republican-lean of the crowd, and playing at home appear to have had no significant effect on player performance (as measured by overall grade).

Assessing only the effect of pregame protest on performance (see Table 3, Model 1), neither players who knelt during the anthem nor players engaged in other protest had overall grades that were significantly different from non-protesting players. These findings proved to be consistent even as we controlled for a range of other factors in Models 2-5. Similarly, neither measure of teammate protests (Models 4-5) had statistically significant effects on performance. Finally, to allow for the possibility that pregame protest may negatively affect performance in the subsequent week's game, in Model 5, we incorporated lagged measures of protest. Neither of these had a significant effect on overall grade. In sum, while a number of factors did help predict which players had the highest grade for a given game, neither a player's current or past week protest nor the protests of their teammates appeared to affect their individual performance ${ }^{4}$.

Our final research question considers whether pregame protest affected the team's performance. In the following analyses, positive values indicated over-performance relative to the betting spread and negative values reflected under-performance relative to expectations. Figure 2 is a scatterplot depicting the number of players kneeling during the anthem on a team and the team's performance relative to the betting spread. Figure 3 similarly shows the number of players engaged in other protest and performance relative to sportsbook expectations. Neither of the figures revealed an apparent relationship between protest and team performance.

\footnotetext{
${ }^{4}$ Given the racial dynamics involved in the motivations for and reactions to the NFL national anthem protests, we tested the possibility that protest may have differential effects on performance for Black and non-Black players. To do so, we included Black $x$ kneel and Black $x$ other protest interaction terms in our player-level models, which were non-significant in both cases. We also tested separate regression models for Black and non-Black players, and the coefficients for the effects of both forms of protest were similarly small in magnitude and non-significant across the two models, indicating that race does not moderate the effect of protest on performance.
} 
To examine this question more systematically, we used OLS regression to examine the association between protests and team performance, controlling for a number of factors (see Table 4). In Model 1, which includes only variables for the estimated numbers of players kneeling and engaging in other forms of protest, we saw no significant effect of either protest measure on performance relative to expectations. This non-effect persisted in Models 2-3 as correlates were added into model. In fact, the only significant variable predicting over-performance relative to betting expectations was the team-wide mean player grade - a post-game measure. Taken together, these findings suggest that there was no evidence for the distraction hypothesis at either the player or team level.

\section{Discussion}

Sport participants and observers have offered many justifications for stifling athlete activism, but one of the more recent rationalizations argues that protest will distract players from succeeding at their most important task - performing on the field toward the goal of winning games. The widespread player demonstrations for racial justice during the 2017 NFL season provided an ideal case study to examine this proposition. Using a unique data set constructed from multiple sources, we found no evidence that pregame protest during the national anthem hindered the in-game performance of NFL football players or teams. The findings were robust in that our analysis indicated that individual players do not play worse when they or their teammates protest, nor do teams suffer detrimental game outcomes as more of their players engage in pre-game activism.

We did find some factors related to the likelihood of demonstrating during the national anthem among NFL players. In particular, Black players were more likely to protest, and especially to kneel, than non-Black players. This finding that is not particularly surprising as the intent of their collective action was to draw attention to police killings of unarmed Black men. The relative reluctance of non-Black players to protest, if not for the cause then at least in support of their Black teammates, may be disappointing though not unexpected. White Americans in particular have historically viewed racial injustice as a problem to be solved by people of color themselves, including outright resistance to challenging violent police action against racial minorities (e.g., Drakulich et al. 2020; Intravia et al., 2018; 
Wheelock et al., 2019). This reluctance on the part of White players is likely exacerbated by media framing of athletic protest being outside the mainstream, leading them to fear that they are risking their careers for a cause that will not directly benefit them (Coombs et al., 2019).

From a team performance perspective, some players may actively believe in the distraction hypothesis and therefore avoid political acts they view as being divisive in the locker room. Yet, players were more likely to protest when their teammates also protested, possibly a result of a threshold effect (Granovetter 1978), a desire to promote team cohesion, peer pressure, or some combination thereof. Kneeling during the national anthem was more common at home stadiums, suggesting that players were more comfortable demonstrating in front of friendly fans, although the effect was in the opposite direction for other forms of protest. Interestingly, players on teams that were betting underdogs for a given game were more likely to protest, maybe feeling they had less at risk in doing so before a game they were not expected to win.

Most importantly, none of our measures of protest - regardless of the type or whether assessed at the individual or team level—were significantly related to our measures of player and team performance; in fact, they explained virtually zero variance in the outcomes. This null finding is strong evidence against the distraction hypothesis, although it should be noted that protest did not bolster individual or team performance either. It is possible that individual athletes may be positively or negatively motivated by the emotion and attention related to their public activism. But that if that is the case, such effects are quite limited and likely washed out by the larger, collective patterns; there is no evidence of a systematic relationship between protest and performance in either direction.

Our findings suggest that it is unlikely that the lack of a protest effect is due to measurement error in the dependent variables. We were able to confirm a number of significant and expected relationships between player grades and other predictors in the model, particularly those that were proxies of player quality, such as salary, years remaining on contract, and total snaps played. We found fewer significant relationships in the models predicting team performance, but that may be due to a somewhat conservative outcome measure in which final game scores were adjusted relative to bookmakers' predictions. Still, we 
did confirm that higher average player grades were strongly and positively related to teams overperforming relative to expectations, giving us confidence in our operationalization of team performance.

Our findings suggest that NFL players can engage in overt political acts before a game without jeopardizing their performance or that of their team on the field. Unlike research on motor behavior impairment that introduces distraction during physical activity (e.g., Grabiner \& Troy, 2005; SheikNanier et al., 2015; Weerdesteyn et al., 2003), there may simply be enough time between the "distraction" of protest and the subsequent game participation that cognitive resources are not affected and stress returns to normal levels before kickoff. Of course, it is also the case that NFL players are elite professional athletes whose training, experience, instinct, and focus likely kick in as soon as the game begins. But it may also be that the simple act of kneeling or raising a fist during the national anthem is not enough to interrupt pregame routines (Glazier 2017), or that professional football players are able to mentally compartmentalize those acts from the rest of their pregame preparations.

Similarly, team cohesion seems unaffected by the number of players engaging in pregame protest, at least in ways that show up during on-field performance. In contrast to research that demonstrates how detrimental distraction is to the functioning of surgical teams (e.g., D'Esmond, 2016; Gui et al., 2021; Wheelock, et al., 2015), there again may be enough of a lag between the pregame protest and the start of gameplay that players do conceive of kneeling, raising a fist, or locking arms as a team distraction. Regardless, these protests did not seem to effect overall team morale (to galvanize or to create resentment) or expose existing social divisions in the locker room that carried over to performance on the field. Professional football players appear able to maintain both task cohesion and social cohesion despite clear differences within teams in social backgrounds, political ideologies, and willingness to take political action (Filho et al., 2015).

Even if protest has no detrimental effects on the field, it has real and profound effects off it. Certainly, there are financial risks for all players if a backlash to protest causes ticket and television revenues decline and for the protesting players in particular if they lose endorsements and coaching 
opportunities (Coombs et al., 2019; Watanabe et al., 2019). An obvious example is the most prominent activist NFL player, Colin Kaepernick, was never signed by an NFL team after the 2016 season, despite being only 29 years old, posting a quarterback rating in the top 20 of all NFL starters, and having recently led the 49ers to the Super Bowl. Instead, critics of Kaepernick, including former players who relished his rejection by NFL teams, argued that his skills had deteriorated to the point where having him in the locker room was not worth the distraction; basically, that his political activity took more away from the team than his quarterbacking talent added (e.g., McManamon, 2017). Although we may never know if Kaepernick was truly "blackballed" out of the league due to a secret agreement or an unstated understanding among NFL owners, he and Eric Reid did receive a multimillion-dollar payment in early 2019 from the NFL to settle a lawsuit alleging collusion against the league (Perez, 2019). The NFL's official website lists Kaepernick as "retired," although Kaepernick has never filed retirement papers and continues to publicly state that he wants to return to the league (Florio, 2020).

Like all studies, our work here contains some limitations that could be addressed by future research. First, we have documented general, sociological patterns that may not necessarily apply to individuals. Future studies should examine specific characteristics of players that may make them more vulnerable or resilient to the effects of pre-game protest. For example, we used professional athletes as our study cases, who as discussed above may be less prone to or affected by distraction than amateur athletes. Future work could look at protest among college or even high school athletes to see if it affects their in-game performance detrimentally. Second, although we suspect that team sports would be more susceptible to pre-game protest effects because of their potential to harm to both individual pre-game routines and team cohesion, future studies should examine individual sports in which protesting athletes do not have the benefit of teammates' social support before, during, and after competition. Third, while we rely on relatively objective measures of performance, future work might find different effects using other indicators of the quality of play of individuals and teams. Fourth, and relatedly, future studies could examine whether athlete activism negatively affects subjective evaluations of in-game performance by team management, media analysts, or fans. 
Even if subsequent studies replicate the findings reported here, we do not expect that the distraction hypothesis will disappear as a common argument used to criticize protest in the sports realm. Granted, there are probably committed adherents to the utility of this idea, particularly among team management and coaches. But we suspect that the distraction hypothesis is often employed insidiously by those who want to present a purely sports-based reason for suppressing protest without revealing their true political and social opposition to athletes' causes. At the same time, the distraction hypothesis reduces athletes from fully realized humans to game playing machines (i.e., "shut up and play"), essentially suggesting that the only worthwhile contributions that they can and should make to society are physical acts for our entertainment. Regardless, the evidence we have presented here suggests that the notion that protest leads to distraction that inhibits game performance is not a legitimate reason to constrain political or social activism by athletes. 


\section{References}

Agyemang, K., Singer, J. N., \& Delorme, J. (2010). An exploratory study of black male college athletes' perceptions on race and athlete activism. International Review for the Sociology of Sport, 45(4): 419-435.

Agyemang, K. J., Singer, J. N., \& Weems, A. J. (2020). 'Agitate! Agitate! Agitate!': Sport as a site for political activism and social change. Organization, 27(6), 952-968.

Bass, A. (2004). Not the triumph but the struggle: The 1968 Olympics and the making of the black athlete. University of Minnesota Press.

Bieler, D. (2017, July 12). Joe Montana calls Colin Kaepernick 'distraction,' likens QB skills to those of Tim Tebow. Washington Post. https://www.washingtonpost.com/news/earlylead/wp/2017/07/12/joe-montana-calls-colin-kaepernick-distraction-likens-qb-skills-to-those-oftim-tebow/?utm_term $=.684 \mathrm{f} 83331750$

Boykoff, J. (2017). Protest, activism, and the Olympic Games: An overview of key issues and iconic moments. The International Journal of the History of Sport, 34(3-4): 162-183.

Brinson, W. (2016, September 27). Here's how Nate Boyer got Colin Kaepernick to go from sitting to kneeling. CBS Sports. https://www.cbssports.com/nfl/news/heres-how-nate-boyer-got-colinkaepernick-to-go-from-sitting-to-kneeling/

Brooks, D. D., \& Althouse, R. (2009). Revolt of the black athlete: From global arena to the college campus. Journal for the Study of Sports and Athletes in Education, 3(2): 195-214.

Bryant, H. (2018). The heritage: Black athletes, a divided America, and the politics of patriotism. Beacon Press.

Carron, A. V., Brawley, L. R., \& Widmeyer, W. N. (1998). Measurement of cohesion in sport and exercise. In J. L. Duda (Ed.), Advances in sport and exercise psychology measurement (pp. 213226). Fitness Information Technology.

Carron, A. V., Colman M. M., Wheelers, J., \& Stevens, D. (2002). "Cohesion and performance in sport: A meta analysis.” Journal of Sport \& Exercise Psychology, 24(2): 168-188.

Chaplin, K. S., \& Montez de Oca, J. (2019). Avoiding the issue: University students' responses to NFL players' national anthem protests." Sociology of Sport Journal, 36(1): 12-21.

Clarke, L., \& Maske, M. (2018, April 6). 'You can't have distractions': Tired of politics, NFL wants to get back to selling football. Washington Post. https://www.washingtonpost.com/sports/tired-ofpolitics-nfl-wants-to-get-back-to-what-it-does-best-selling-football/2018/04/06/6d770e 7e-344811e8-8abc-22a366b72f2d_story.html

Cooky, C., \& Antunovic, D. (2020). 'This isn't just about us': Articulations of feminism in media narratives of athlete activism. Communication \& Sport, 8(4-5), 692-711.

Cohn, P. J. (1990). Preperformance routines in sport: Theoretical support and practical applications. The Sport Psychologist, 4(3): 301-312. 
Coombs, D. S., \& Cassilo, D. (2017). Athletes and/or activists: LeBron James and Black Lives Matter. Journal of Sport and Social Issues, 41(5): 425-444.

Coombs, D. S., Lambert, C. A., Cassilo, D., \& Humphries, Z. (2019). Flag on the play: Colin Kaepernick and the protest paradigm. Howard Journal of Communications, 31(4): 317-336.

Cooper, J. N., Macaulay, C., \& Rodriguez. S. H. (2019). Race and resistance: A typology of African American sport activism. International Review for the Sociology of Sport, 54(2): 151-181.

Cunningham, G. B., Dixon, M. A., Singer, J. N., Oshiro, K. F., Ahn, N. Y., \& Weems, A. (2019). A site to resist and persist: Diversity, social justice, and the unique nature of sport. Journal of Global Sport Management, 6(1), 30-48.

Cunningham, G.B., \& Gill, Jr., E.J. (2016). 'Hands up, don't shoot' or shut up and play ball? Fangenerated media views of the Ferguson Five. Journal of Human Behavior in the Social Environment, 26(3-4), 400-412.

Cunningham, G. B., \& Regan, M. R. (2011). Political activism, racial identity and the commercial endorsement of athletes. International Review for the Sociology of Sport, 47(6): 657-669.

D'Esmond, L. K. (2016). Distracted practice and patient safety: The healthcare team experience. Nursing Forum, 52(3): 149-164.

Dickerson, N., \& Hodler, M. (2020). 'Real men stand for our nation': Constructions of an American nation and anti-Kaepernick memes. Journal of Sport and Social Issues. https://doi.org/10.1177/0193723520950537

Dobersek, U., Gershgoren, L., Becker, B., \& Tenenbaum, G. (2014). The cohesion-performance relationship in sport: A 10-year retrospective meta-analysis. Sport Sciences for Health, 10(3): 165-177.

Dodson, K. (2016). Economic threat and protest behavior in comparative perspective. Sociological Perspectives, 59(4): 873-891.

Drakulich, K., Wozniak, K. H., Hagan, J., \& Johnson, D. (2020). Race and policing in the 2016 presidential election: Black Lives Matter, the police, and dog whistle politics. Criminology, 58(2) $370-402$.

Edwards, H. (2017 [1969]). The revolt of the black athlete. University of Illinois Press.

ESPN.com staff. (2017, December 31). NFL Players who protested during national anthem in week 17. ESPN.com. https://www.espn.com/blog/nflnation/post//id/264431/nfl-players-who-protestedduring-national-anthem-in-week-17

Farrar, D. (2014, July 21). Why Tony Dungy wouldn't have drafted Michael Sam. Sports Illustrated. https://www.si.com/nfl/2014/07/21/why-tony-dungy-wouldnt-have-drafted-michael-sam

Filho, E., Tenenbaum, G., \& Yang, Y. (2015). Cohesion, team mental models, and collective efficacy: Towards an integrated framework of team dynamics in sport. Journal of Sports Sciences, 33(6): 641-653. 
Florio, M. (2020, May 22). Redesigned NFL.com lists Colin Kaepernick as 'retired.' NBC Sports. https://profootballtalk.nbcsports.com/2020/05/22/redesigned-nfl-com-lists-colin-kaepernick-asretired/

FootballLocks.com. (n.d.) Closing NFL odds from the 2017-2018 season. Retrieved June 1, 2020 from http://www.footballlocks.com/nfl odds_2017 2018.shtml

Galily, Y. (2020). 'Shut up and dribble!'? Athletes activism in the age of twittersphere: The case of LeBron James. Technology in Society, 58, 101109.

Gill, Jr., E. L. (2016). 'Hands up, don't shoot' or shut up and play ball? Fan-generated media views of the Ferguson Five. Journal of Human Behavior in the Social Environment, 26(3-4): 400-412.

Gius, M., \& Johnson, D. (2000). Race and compensation in professional football. Applied Economics Letters, 7(2):73-75.

Glazier, P. S. (2017). Towards a grand unified theory of sports performance. Human Movement Science, 56: 139-156.

Goudsouzian, A. (2017). From Lew Alcindor to Kareem Abdul-Jabbar: Race, religion, and representation in basketball, 1968-195. Journal of American Studies, 51(2): 437-470.

Grabiner, M. D., \& Troy, K. L. (2005). Attention demanding tasks during treadmill walking reduce step width variability in young adults. Journal of NeuroEngineering and Rehabilitation, 2 , https://doi.org/10.1186/1743-0003-2-25

Granovetter, M. (1978). Threshold models of collective behavior. American Journal of Sociology, 83(6): $1420-1443$.

Green, K., \& Hartmann, D. (2012, February 3). Politics and sports: Strange, secret bedfellows. The Society Pages. https://thesocietypages.org/papers/politics-and-sport/

Gui, J. L., Nemergut, E. C., Forkin, K. T. (2021). Distraction in the operating room: A narrative review of environmental and self-initiated distractions and their effect on anesthesia providers. Journal of Clinical Anesthesia, 68: https://doi.org/10.1016/j.jclinane.2020.110110

Harris, O. (1995). Muhammad Ali and the revolt of the black athlete. In E. J. Gorn (Ed.), Muhammad Ali: The people's champ (pp. 54-69). University of Illinois Press.

Hartmann, D. (2003). Race, culture, and the revolt of the black athlete: The 1968 Olympic protests and their aftermath. University of Chicago Press.

Hartmann, D. (2009). Activism, organizing, and the symbolic power of sport: Reassessing Harry Edwards's contributions to the 1968 Olympic protest movement. Journal for the Study of Sports and Athletics in Education, 3(2): 181-195.

Hartmann, D. (2019). The Olympic 'revolt' of 1968 and its lessons for contemporary African American athletic activism." European Journal of American Studies, 14-1. https://doi.org/10.4000/ejas.14335 
Hartmann, D. (forthcoming). Sport, social movements, and athlete activism. In L. Werner (Ed.), Oxford handbook of sport \& society.

Hazell, J., Cotterill, S. T., \& Hill, D. M. (2014). An exploration of pre-performance routines, selfefficacy, anxiety, and performance in semi-professional soccer. European Journal of Sport Science, 14(6): 603-610.

Houghteling, C., \& Dantzler, P. A. (2019). Taking a knee, taking a stand: Social networks and identity salience in the 2017 NFL protests. Sociology of Race and Ethnicity. https://doi.org/10.1177/2332649219885978

Intravia, J., Piquero, A., \& Piquero, N. L. (2018). The racial divide surrounding the United States of America national anthem protests in the National Football League. Deviant Behavior, 39(8): 1058-1068.

Jensen, C. (2017, September 26). Were the 'take a knee' protests a distraction for the Broncos? 247Sports. https://247sports.com/nfl/denver-broncos/Article/Were-The-Take-A-Knee-Protests-ADistraction-For-The-Denver-Broncos--108009118/

Kahn, L. M. (1992). The effects of race on professional football players' compensation. Industrial and Labor Relations Review, 45(2): 295-310.

Kaufman, P. (2008). Boos, bans, and other backlash: The consequences of being an activist athlete. Humanity and Society, 32: 215-237.

Kaufman, P., \& Wolff, E. A. (2010). Playing and protesting: Sport as a vehicle for social change. Journal of Sport and Social Issues, 34(2): 154-175.

Kilcline, C. (2017). Sport and protest: Global perspectives. The International Journal of the History of Sport, 34(3-4): 157-161.

Krippendorf, K. (2013). Content analysis: An introduction to its methodology. Sage.

LaPlaca, D. A., \& McCullick, B. A. (2020). National Football League scouting combine tests correlated to National Football League player performance. The Journal of Strength \& Conditioning Research, 34(5): 1317-1329.

Lavelle, K. L. (2019). 'Change starts with us': Intersectionality and citizenship in the 2016 WNBA. In D.A. Grano \& M.L Buttersworth (Eds.), Sport, rhetoric, and political struggle, (pp. 39-54). Peter Lang.

Lee, W., \& Cunningham, G. B. (2019). Moving toward understanding social justice in sport organizations: A study of engagement in social justice advocacy in sport organizations. Journal of Sport and Social Issues, 43(3), 245-263.

Marinelli, K. (2008). Placing second: Empathic unsettlement as a vehicle of consubstantiality at the silent gesture statue of Tommie Smith and John Carlos. Memory Studies, 10(4): 440-458.

McManamon, P. (2017, March 26). Joe Thomas: NFL teams view Colin Kaepernick as unworthy distraction. ESPN.com. https://www.espn.com/nfl/story/ /id/19011238/colin-kaepernick-vieweddistraction-joe-thomas-cleveland-browns-says 
Mirer, M., \& Grubic, A. (2019). Promotional space or public forum: Protest coverage and reader response in team-operated media. Communication \& Sport. https://doi.org/10.1177/2167479519894997

Moran, A. P. (2016). The psychology of concentration in sport performers: A cognitive analysis. Routledge.

Nauright, J., \& Wiggins, D. K. (2017). Sport and revolutionaries: Reclaiming the historical role of sport in social and political activism. Routledge.

Nepstad, S. E., \& Kenney, A. M. (2018). Legitimation battles, backfire dynamics, and tactical persistence in the NFL anthem protests, 2016-2017. Mobilization: An International Quarterly, 23(4): 469483.

NFL.com. (n.d.) League schedule 2017. Retrieved June 1, 2020 from https://www.nfl.com/schedules/2017/reg1/

Niven, D. (2019). The effect of economic vulnerability on protest participation in the National Football League. Social Science Quarterly, 100(4): 997-1008

O'Bonsawin, C. (2015). From black power to indigenous activism: The Olympic movement and the marginalization of oppressed peoples, 1968-2012. Journal of Sport History, 42(2): 200-219.

Paine, N., Enten, H., \& Jones-Rooy, A. (2017, September 29). How every NFL team's fans lean politically. FiveThirtyEight.com. https://fivethirtyeight.com/features/how-every-nfl-teams-fanslean-politically/

Perez, A. J. (2019, March 21). Report: Colin Kaepernick, Eric Reid got less than \$10 million in NFL collusion settlement. USA Today. https://www.usatoday.com/story/sports/nfl/2019/03/21/colinkaepernick-eric-reid-nfl-collusion-settlement/3237678002/

Polite, F. G., \& Hawkins, B. (2012). Sport, race, activism, and social change: The impact of Dr. Harry Edwards' scholarship and service. Cognella.

Pro Football Focus. (n.d.). PFF grades. Retrieved June 1, 2020 from https://pff.com/grades

Ratchford, J. (2012). Black fists and fool's gold: The 1960s black athletic revolt reconsidered: The Lebron James decision and self-determination in post-racial America. Black Scholar, 42(1): 4959.

Ruffin II, H. G. (2014). 'Doing the right thing for the sake of doing the right thing': The revolt of the black athlete and the modern student-athletic movement, 1956-2014. The Western Journal of Black Studies, 38(4): 260-278.

Schippers, M. C., \& Van Lange, P. A. M. (2006). The psychological benefits of superstitious rituals in top sport: A study among top sportspersons. Journal of Applied Social Psychology, 36(10): 25322553.

Schmidt, S. H., Frederick, E. L., Pegoraro, A., \& Spencer, T. (2019). An analysis of Colin Kaepernick, Megan Rapinoe, and the national anthem protests. Communication \& Sport, 7(5): 653-677. 
Schmittel, A., \& Sanderson, J. (2015). Talking about Trayvon in 140 characters: Exploring NFL players' tweets about the George Zimmerman verdict. Journal of Sport and Social Issues, 39(4): 332-345.

Sheik-Nanier, M., Kaber, D., Hsiang, S., Panok, Jr., C., \& Zahabi, M. (2015). Influence of cognitive and perceptual processing on multitask performance with locomotion. Theoretical Issues in Ergonomics Science, 16(3): 273-298.

Smith, B., \& Tryce, S. A. (2019). Understanding emerging adults' national attachments and their reactions to athlete activism. Journal of Sport and Social Issues, 43(3), 167-194.

Spotrac. (n.d). NFL contracts. Retrieved June 1, 2020 from https:/www.spotrac.com/nfl/contracts/

Steele, D. (2018, February 6). Protests a 'distraction'? No for Eagles, still yes for NFL. Sporting News. https://www.sportingnews.com/us/nfl/news/nfl-protests-national-anthem-distraction-philadelphiaeagles-super-bowl-white-house/s558gaaby53g1kugmh2i8zfow

Tatum, S. (2017, September 23). Trump: NFL owners should fire players who protest the national anthem. CNN.com. https://www.cnn.com/2017/09/22/politics/donald-trump-alabamanfl/index.html

Van Valkenburg, K. (2013, November 22). A week in the life of a coach. ESPN.com. http://www.espn.com/nfl/story//id/10012376/baltimore-ravens-head-coach-john-harbaughclocks-long-hours-prep-game-day-espn-magazine

Volz, B. D. (2017). Race and quarterback survival in the National Football League. Journal of Sports Economics, 18(8): 850-866.

Wagoner, N. (2016, September 1). Colin Kaepernick takes knee for anthem; joined by teammate Eric Reid. ESPN.com. https:/www.espn.com/nfl/story//id/17444691/colin-kaepernick-san-francisco49ers-sits-again-national-anthem

Watanabe, N. M., \& Cunningham, G. B. (2020). The impact of race relations on NFL attendance: An econometric analysis. PLOS ONE, 15(1). https://doi.org/10.1371/journal.pone.0226938

Watanabe, N., Yan, G., \& Soebbing, B. P. (2019). Market disruption as a regime for athlete activism: An economic analysis of college football player protests. Sport Management Review, 22: 600-612.

Weerdesteyn, V., Schillings, A. M., van Galen, G. P., and Duysens, J. (2003). Distraction affects the performance of obstacle avoidance during walking. Journal of Motor Behavior, 35(1): 53-63.

Weffer, S. E., Rodrigo Dominguez-Martinez, R., \& Jenkins, R. (2018). Taking a knee. Contexts, 17: 6668.

Wheelock, A. Suliman, A., Wharton, R., Babu, E. D., Hull, L. Vincent, C., Sevdalis, N., \& Arora, S. (2015). The impact of operating room distractions on stress, workload, and teamwork. Annals of Surgery, 261(6): 1079-1084.

Wheelock, D., Stroshine, M. S., \& O'Hear, M. (2019). Disentangling the relationship between race and attitudes toward the police: Police contact, perceptions of safety, and procedural justice. Crime \& Delinquency, 65(7): 941-968. 
Wiggins, D. K. (1988). The future of college athletics is at stake: Black athletes and racial turmoil on three predominantly white university campuses, 1968-1972. Journal of Sport History, 15(3): 304333.

Wyche, S. (2016, August 27). Colin Kaepernick explains why he sat during national anthem. NFL.com. https://www.nfl.com/news/colin-kaepernick-explains-why-he-sat-during-national-anthem$\underline{0 \text { ap3000000691077 }}$

Zaporzan, P. (2019). Taking a knee: Estimating the impacts of national anthem protests in the National Football League on salary and performance. [Master's thesis, University of Ottawa]. University of Ottawa Library. 


\section{TABLES}

Table 1. Descriptive Statistics

Mean Median $\quad$ SD $\quad$ Min $\quad$ Max

\begin{tabular}{|c|c|c|c|c|c|}
\hline \multicolumn{6}{|l|}{ Player-Games Measures $(n=19,051)$} \\
\hline \multicolumn{6}{|l|}{ Game Variant } \\
\hline Player, Kneel Anthem & 0.01 & 0.00 & 0.09 & 0.00 & 1.00 \\
\hline Player, Other Protest & 0.07 & 0.00 & 0.25 & 0.00 & 1.00 \\
\hline Team, Estimated Players Kneeling & 0.72 & 0.00 & 3.55 & 0.00 & 40.00 \\
\hline Team, Estimated Players Other Protest & 5.43 & 0.00 & 13.97 & 0.00 & 53.00 \\
\hline Player Kneel, Week Lag & 0.01 & 0.00 & 0.09 & 0.00 & 1.00 \\
\hline Player Other Protest, Week Lag & 0.07 & 0.00 & 0.26 & 0.00 & 1.00 \\
\hline Player Performance Grade & 62.60 & 64.50 & 15.93 & 10.50 & 99.90 \\
\hline Player Total Snaps & 39.17 & 40.00 & 23.25 & 1.00 & 91.00 \\
\hline Home Game & 0.50 & 1.00 & 0.50 & 0.00 & 1.00 \\
\hline Betting Spread & 0.00 & 0.00 & 6.37 & -16.50 & 16.50 \\
\hline GOP Lean of Stadium Crowd & 1.94 & 1.95 & 0.08 & 1.78 & 2.10 \\
\hline Weeks $3 \& 4$ & 0.13 & 0.00 & 0.33 & 0.00 & 1.00 \\
\hline \multicolumn{6}{|l|}{ Game Invariant } \\
\hline Black & 0.75 & 1.00 & 0.44 & 0.00 & 1.00 \\
\hline Age & 26.14 & 26.00 & 3.17 & 20.00 & 40.00 \\
\hline Years Remaining on Contract & 3.21 & 4.00 & 1.31 & 1.00 & 8.00 \\
\hline Salary (in Millions of Dollars) & 3.38 & 1.42 & 4.18 & 0.08 & 27.00 \\
\hline Offensive Skill Position (reference category) & -- & -- & -- & -- & -- \\
\hline Offensive Lineman & 0.16 & 0.00 & 0.37 & 0.00 & 1.00 \\
\hline Defensive Position & 0.51 & 1.00 & 0.50 & 0.00 & 1.00 \\
\hline \multicolumn{6}{|l|}{ Team-Games Measures $(n=512)$} \\
\hline Estimated Players Kneeling & 0.72 & 0.00 & 3.55 & 0.00 & 40.00 \\
\hline Estimated Players Other Protest & 5.39 & 0.00 & 13.93 & 0.00 & 53.00 \\
\hline Actual Score - Betting Spread & 0.00 & 0.00 & 13.15 & -45.50 & 45.50 \\
\hline Mean Player Performance Grade & 62.61 & 62.62 & 3.39 & 51.99 & 71.35 \\
\hline Sum of Snaps & 1457.36 & 1451.00 & 96.96 & 1207.00 & 1870.00 \\
\hline Home Game & 0.50 & 0.50 & 0.50 & 0.00 & 1.00 \\
\hline GOP Lean of Stadium Crowd & 1.94 & 1.95 & 0.08 & 1.78 & 2.10 \\
\hline Weeks $3 \& 4$ & 0.13 & 0.00 & 0.33 & 0.00 & 1.00 \\
\hline Percent Black & 74.57 & 74.36 & 6.28 & 55.56 & 90.24 \\
\hline Mean Player Age & 26.14 & 26.14 & 0.65 & 23.86 & 28.23 \\
\hline Mean Years Remaining on Contract & 3.21 & 3.23 & 0.25 & 2.56 & 3.91 \\
\hline Mean Salary (in Millions of Dollars) & 3.38 & 3.44 & 0.57 & 1.29 & 4.68 \\
\hline
\end{tabular}


Table 2. Multinomial Logistic Regression Analysis of Forms of Protest (Relative Risk Ratios)

\begin{tabular}{|c|c|c|c|}
\hline No Protest (base outcome) & (1) & (2) & (3) \\
\hline \multicolumn{4}{|l|}{ Other Protest } \\
\hline \multirow[t]{2}{*}{ Black } & 1.129 & 1.223 & $1.622 *$ \\
\hline & $(0.121)$ & $(0.161)$ & $(0.327)$ \\
\hline \multirow[t]{2}{*}{ Age } & 0.990 & 0.985 & 0.994 \\
\hline & $(0.018)$ & $(0.024)$ & $(0.040)$ \\
\hline \multirow[t]{2}{*}{ Years on Contract } & 0.952 & 0.952 & 0.881 \\
\hline & $(0.036)$ & $(0.048)$ & $(0.073)$ \\
\hline \multirow{2}{*}{ Salary (in Millions) } & 1.017 & 1.024 & 1.067 \\
\hline & $(0.016)$ & $(0.021)$ & $(0.039)$ \\
\hline \multirow{2}{*}{ Offensive Skill Position } & -- & -- & -- \\
\hline & -- & -- & -- \\
\hline \multirow[t]{2}{*}{ Offensive Linemen } & 1.028 & 1.079 & 1.134 \\
\hline & $(0.140)$ & $(0.182)$ & $(0.300)$ \\
\hline \multirow[t]{2}{*}{ Defensive Position } & 1.184 & 1.256 & 1.456 \\
\hline & $(0.121)$ & $(0.159)$ & $(0.285)$ \\
\hline \multirow[t]{2}{*}{ Home Game } & & $0.929^{* *}$ & $0.814 * *$ \\
\hline & & $(0.062)$ & $(0.062)$ \\
\hline \multirow[t]{2}{*}{ Betting Spread } & & $1.055^{* * *}$ & $1.072 * * *$ \\
\hline & & $(0.008)$ & $(0.015)$ \\
\hline \multirow[t]{2}{*}{ GOP Lean of Stadium Crowd } & & $0.003 * * *$ & $0.123^{*}$ \\
\hline & & $(0.002)$ & $(0.102)$ \\
\hline \multirow[t]{2}{*}{ Weeks $3 \& 4$} & & $31.709 * * *$ & $3.162 * * *$ \\
\hline & & $(4.176)$ & $(0.450)$ \\
\hline \multirow[t]{2}{*}{ Team, Estimated Kneel Anthem } & & & 1.003 \\
\hline & & & $(0.006)$ \\
\hline \multirow[t]{2}{*}{ Team, Estimated Other Protest } & & & $1.114 * * *$ \\
\hline & & & $(0.006)$ \\
\hline \multirow[t]{2}{*}{ Constant } & $0.087 * * *$ & $1725.351^{* * *}$ & 0.283 \\
\hline & $(0.045)$ & $(1932.950)$ & $(0.581)$ \\
\hline$N$ & 18,454 & 18,268 & 18,268 \\
\hline Pseudo $R^{2}$ & 0.0108 & 0.2903 & 0.5491 \\
\hline
\end{tabular}


Table 2. Multinomial Logistic Regression Analysis of Forms of Protest (Relative Risk Ratios; Continued)

\begin{tabular}{lccc}
\hline & $(1)$ & $(2)$ & $(3)$ \\
No Protest (base outcome) & & & \\
\hline Knelt During Anthem & $24.701^{* * *}$ & $24.819^{* * *}$ & $27.813^{* * *}$ \\
Black & $(19.621)$ & $(20.047)$ & $(22.766)$ \\
& 1.016 & 0.996 & 0.999 \\
Age & $(0.060)$ & $(0.066)$ & $(0.067)$ \\
& 1.045 & 1.038 & 1.003 \\
Years on Contract & $(0.169)$ & $(0.188)$ & $(0.187)$ \\
& 1.072 & 1.094 & $1.117^{*}$ \\
Salary (in Millions) & $(0.053)$ & $(0.058)$ & $(0.062)$ \\
& -- & -- & -- \\
Offensive Skill Position & -- & -- & - \\
& 0.534 & 0.587 & 0.555 \\
Offensive Linemen & $(0.474)$ & $(0.528)$ & $(0.507)$ \\
& 1.145 & 1.153 & 1.224 \\
Defensive Position & $(0.492)$ & $(0.520)$ & $(0.574)$ \\
& & $1.878^{* * *}$ & $2.461^{* * *}$ \\
Home Game & & $(0.244)$ & $(0.478)$ \\
& & $1.073^{* * *}$ & $1.089^{* * *}$ \\
Betting Spread & & $(0.020)$ & $(0.021)$ \\
GOP Lean of Stadium Crowd & & $0.005^{* *}$ & $0.019^{*}$ \\
& & $0.009)$ & $(0.035)$ \\
Weeks $3 \& 4$ & & $12.077^{* * *}$ & $4.392^{* * *}$ \\
Team, Estimated Kneel Anthem & & $(3.848)$ & $(1.422)$ \\
Team, Estimated Other Protest & & & $1.072^{* * *}$ \\
& & & $(0.010)$ \\
Constant & & & $1.044^{* * *}$ \\
& & & $(0.006)$ \\
Pseudo $R^{2}$ & 0.0108 & 0.2903 & 0.116 \\
Clustered on player; Relative risk ratios; Standard errors in parentheses; $* \mathrm{p}<.05, * * \mathrm{p}<.01, * * * \mathrm{p}<.001$ \\
\end{tabular}


Table 3. Random Effects Linear Regression Analysis of Player Overall Grade

(1) (2) (3)

(4)

(5)

\begin{tabular}{|c|c|c|c|c|c|}
\hline Player, Other Protest & $\begin{array}{l}-0.128 \\
(0.459)\end{array}$ & $\begin{array}{l}-0.339 \\
(0.457)\end{array}$ & $\begin{array}{l}-0.274 \\
(0.457)\end{array}$ & $\begin{array}{l}-0.721 \\
(0.685)\end{array}$ & $\begin{array}{l}-0.572 \\
(0.712)\end{array}$ \\
\hline Player, Kneel Anthem & $\begin{array}{c}0.848 \\
(1.343)\end{array}$ & $\begin{array}{c}-0.046 \\
(1.335)\end{array}$ & $\begin{array}{c}0.827 \\
(1.391)\end{array}$ & $\begin{array}{c}0.890 \\
(1.405)\end{array}$ & $\begin{array}{c}0.222 \\
(1.515)\end{array}$ \\
\hline Black & & $\begin{array}{l}-0.211 \\
(0.367)\end{array}$ & $\begin{array}{l}-0.166 \\
(0.360)\end{array}$ & $\begin{array}{l}-0.153 \\
(0.360)\end{array}$ & $\begin{array}{l}-0.244 \\
(0.376)\end{array}$ \\
\hline Age & & $\begin{array}{c}0.097 \\
(0.059)\end{array}$ & $\begin{array}{c}0.081 \\
(0.058)\end{array}$ & $\begin{array}{c}0.082 \\
(0.058)\end{array}$ & $\begin{array}{c}0.088 \\
(0.061)\end{array}$ \\
\hline Years on Contract & & $\begin{array}{c}0.901 * * * \\
(0.134)\end{array}$ & $\begin{array}{c}0.775 * * * \\
(0.133)\end{array}$ & $\begin{array}{c}0.775 * * * \\
(0.133)\end{array}$ & $\begin{array}{c}0.743 * * * \\
(0.139)\end{array}$ \\
\hline Salary (in Millions) & & $\begin{array}{c}0.631 * * * \\
(0.046)\end{array}$ & $\begin{array}{c}0.567 * * * \\
(0.047)\end{array}$ & $\begin{array}{c}0.567 * * * \\
(0.047)\end{array}$ & $\begin{array}{c}0.556 \text { *** } \\
(0.048)\end{array}$ \\
\hline Offensive Skill Position & $\begin{array}{l}-- \\
--\end{array}$ & -- & $\begin{array}{l}-- \\
--\end{array}$ & $\begin{array}{l}-- \\
--\end{array}$ & $\begin{array}{l}-- \\
--\end{array}$ \\
\hline Offensive Linemen & & $\begin{array}{c}-1.939 * * * \\
(0.460)\end{array}$ & $\begin{array}{c}-2.651 * * * \\
(0.470)\end{array}$ & $\begin{array}{c}-2.653 * * * \\
(0.470)\end{array}$ & $\begin{array}{c}-2.736 * * * \\
(0.493)\end{array}$ \\
\hline Defensive Position & & $\begin{array}{c}2.174 * * * \\
(0.338)\end{array}$ & $\begin{array}{c}1.980 * * * \\
(0.333)\end{array}$ & $\begin{array}{c}1.980 * * * \\
(0.333)\end{array}$ & $\begin{array}{c}1.897 * * * \\
(0.347)\end{array}$ \\
\hline Total Snaps & & & $\begin{array}{c}0.034 * * * \\
(0.006)\end{array}$ & $\begin{array}{c}0.034 * * * \\
(0.006)\end{array}$ & $\begin{array}{c}0.038 * * * \\
(0.007)\end{array}$ \\
\hline Betting Spread & & & $\begin{array}{c}-0.161 * * * \\
(0.020)\end{array}$ & $\begin{array}{c}-0.160 * * * \\
(0.020)\end{array}$ & $\begin{array}{c}-0.163 * * * \\
(0.021)\end{array}$ \\
\hline Home Game & & & $\begin{array}{c}0.211 \\
(0.238)\end{array}$ & $\begin{array}{c}0.190 \\
(0.238)\end{array}$ & $\begin{array}{c}0.117 \\
(0.251)\end{array}$ \\
\hline GOP Lean of Stadium Crowd & & & $\begin{array}{l}-0.571 \\
(1.535)\end{array}$ & $\begin{array}{c}-0.428 \\
(1.542)\end{array}$ & $\begin{array}{l}-0.477 \\
(1.623)\end{array}$ \\
\hline Team, Estimated Kneel Anthem & & & & $\begin{array}{l}-0.033 \\
(0.034)\end{array}$ & $\begin{array}{l}-0.034 \\
(0.035)\end{array}$ \\
\hline Team, Estimated Other Protest & & & & $\begin{array}{c}0.013 \\
(0.013)\end{array}$ & $\begin{array}{c}0.011 \\
(0.013)\end{array}$ \\
\hline Player Kneel, Week Lag & & & & & $\begin{array}{c}1.512 \\
(1.471)\end{array}$ \\
\hline Player Other Protest, Week Lag & & & & & $\begin{array}{l}-0.246 \\
(0.499)\end{array}$ \\
\hline Constant & $\begin{array}{c}62.219^{* * *} \\
(0.158)\end{array}$ & $\begin{array}{c}54.420^{* * *} \\
(1.743)\end{array}$ & $\begin{array}{c}55.338^{* * *} \\
(3.412)\end{array}$ & $\begin{array}{c}55.011 * * * \\
(3.427)\end{array}$ & $\begin{array}{c}55.208 * * * \\
(3.594)\end{array}$ \\
\hline $\begin{array}{l}N \\
R^{2} \text { Between }\end{array}$ & $\begin{array}{c}19,050 \\
0.001\end{array}$ & $\begin{array}{l}18,453 \\
0.2127\end{array}$ & $\begin{array}{l}18,267 \\
0.2371\end{array}$ & $\begin{array}{l}18,267 \\
0.2365\end{array}$ & $\begin{array}{l}16,637 \\
0.2308\end{array}$ \\
\hline
\end{tabular}

Random effects on player; Standard errors in parentheses; ${ }^{*} \mathrm{p}<.05,{ }^{* *} \mathrm{p}<.01,{ }^{* * *} \mathrm{p}<.001$ 
Table 4. Linear Regression Analysis of Team Performance Relative to Betting Spread

\begin{tabular}{lccc}
\hline & $(1)$ & $(2)$ & $(3)$ \\
\hline Team, Estimated Kneel Anthem & -0.233 & -0.165 & -0.085 \\
Team, Estimated Other Protest & $(0.131)$ & $(0.133)$ & $(0.097)$ \\
& 0.045 & 0.027 & -0.002 \\
Home Game & $(0.043)$ & $(0.051)$ & $(0.039)$ \\
& & 0.677 & -1.216 \\
GOP Lean of Stadium Crowd & $(1.608)$ & $(1.279)$ \\
Weeks 3 \& 4 & 1.742 & 3.352 \\
& & $(2.301)$ & $(2.989)$ \\
Percent Black & & 0.584 & 1.128 \\
& & $(1.221)$ & $(1.097)$ \\
Mean Player Age & & 0.006 \\
& & & $(0.074)$ \\
Mean Years Remaining on Contract & & & 0.014 \\
& & & $(0.928)$ \\
Mean Salary (in Millions) & & -3.471 \\
Mean Player Performance Grade & & $(2.182)$ \\
Sum of Snaps & & & -1.311 \\
& & & $(0.945)$ \\
Constant & & & $2.310^{* * *}$ \\
& & & $(0.179)$ \\
$R^{2}$ & & & 0.001 \\
& & & $(0.002)$ \\
\hline
\end{tabular}

Standard errors in parentheses; ${ }^{*} \mathrm{p}<.05,{ }^{* *} \mathrm{p}<.01,{ }^{* * *} \mathrm{p}<.001$ 


\section{FIGURES}

Figure 1

NFL Protests Reported in Media By Week

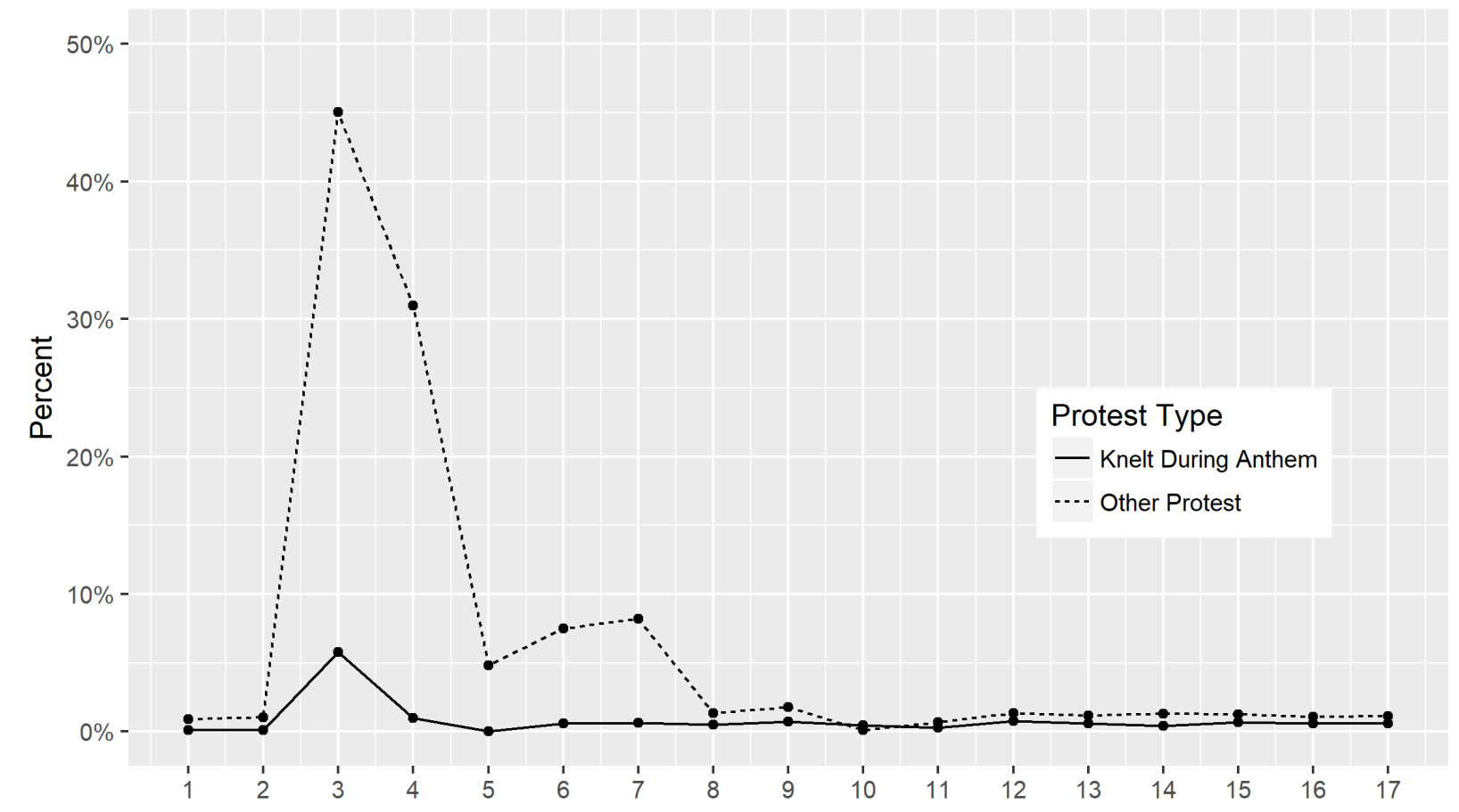


Figure 2

Game Performance and Kneeling Protest

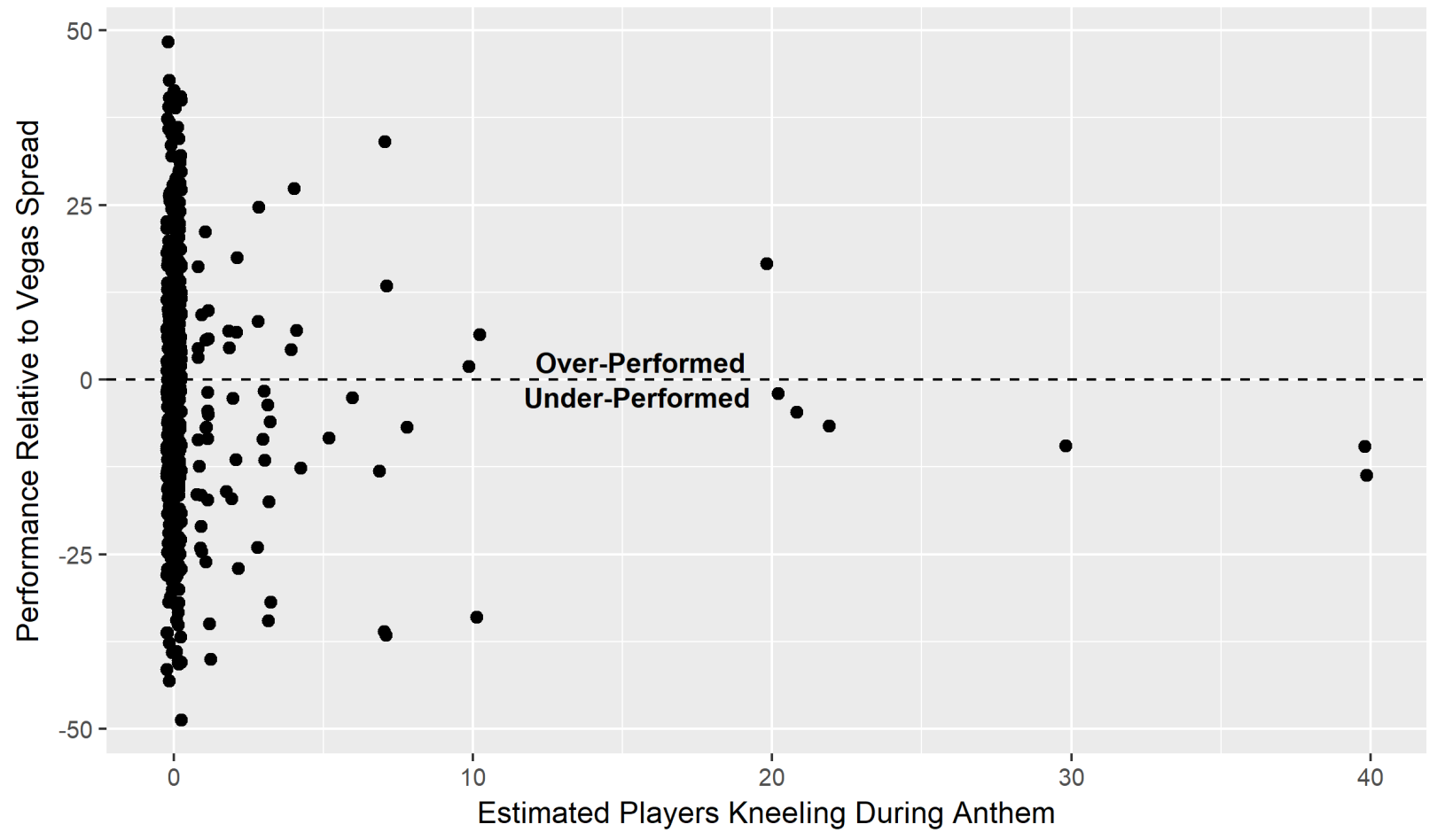


Figure 3

Game Performance and Other Protest

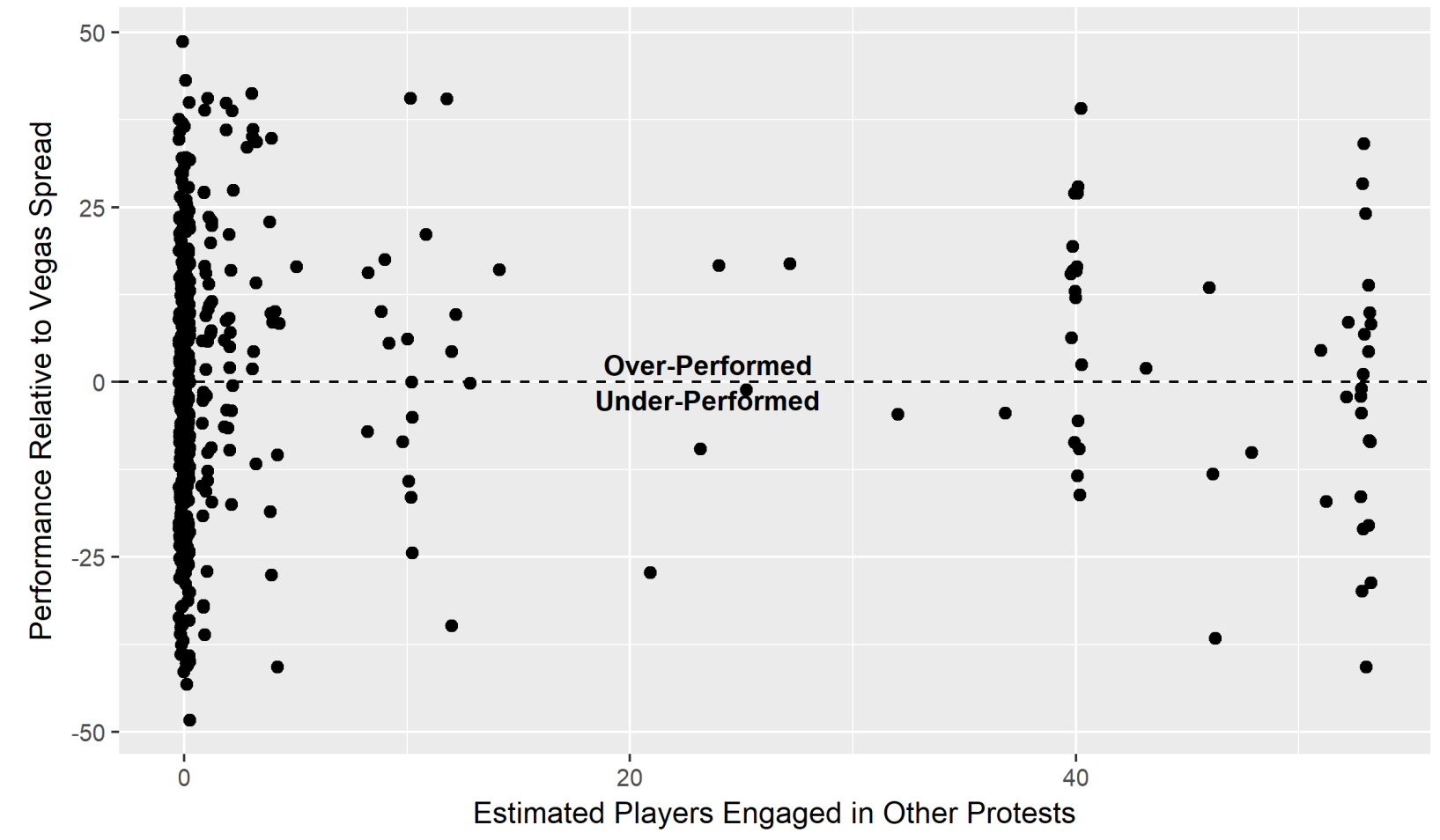

